\title{
Surviving on a mountain of rubbish: the state and access to health social security for female scavengers
}

\section{Bertahan hidup di gunung sampah: Negara dan akses jaminan sosial kesehatan bagi pemulung perempuan}

\author{
Fairus Dwi Putri ${ }^{1}$, Khaerul Umam Noer ${ }^{2}$ \\ ${ }^{1}$ Department of Public Administration, Universitas Muhammadiyah Jakarta, Indonesia. \\ E-mail:fairussdwi@gmail.com \\ ${ }^{2}$ Department of Public Administration, Universitas Muhammadiyah Jakarta, Indonesia. \\ E-mail:umam.noer@umj.ac.id
}

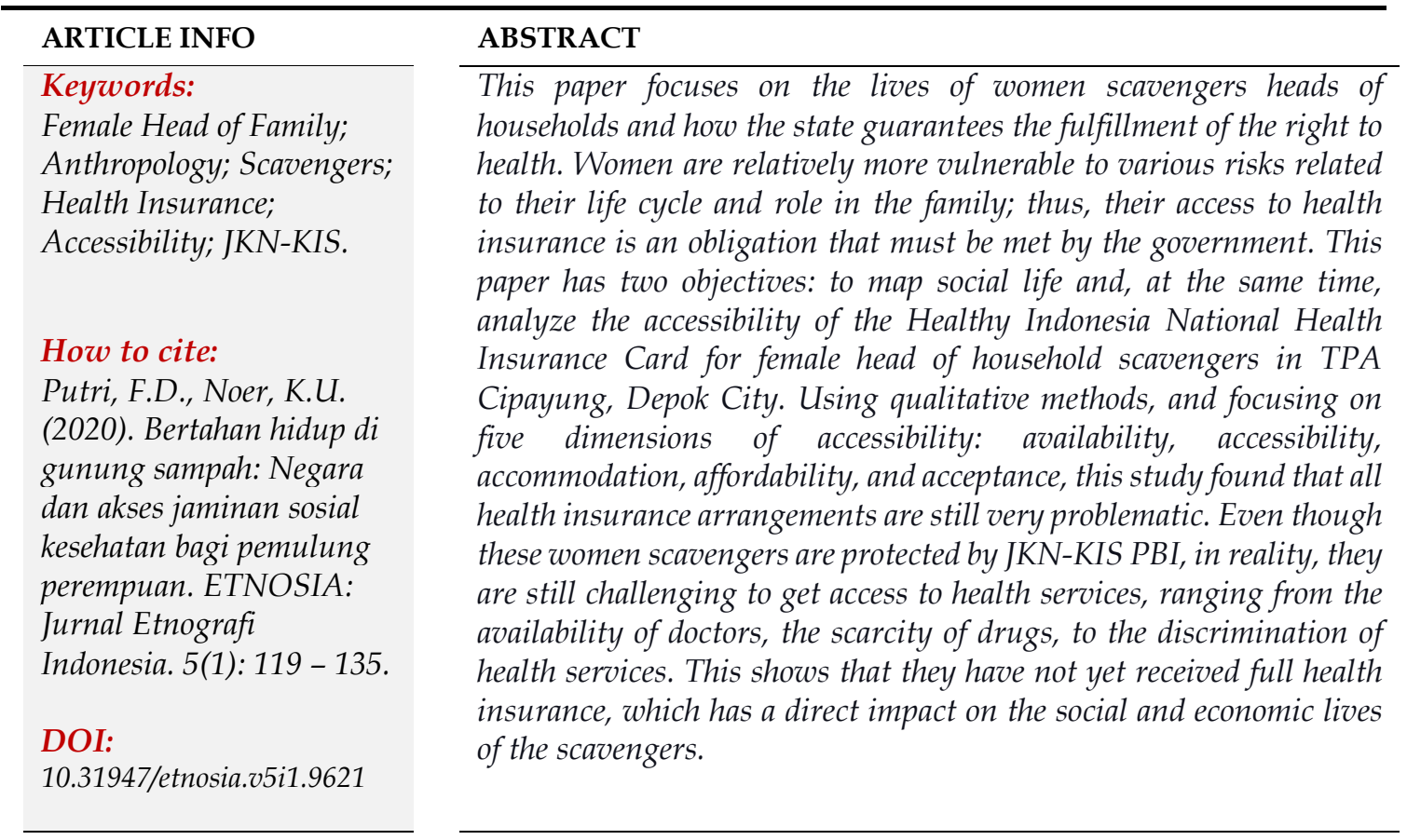

\section{Pendahuluan}

Jaminan sosial adalah intervensi melembaga yang dirancang oleh pemerintah maupun sektor swasta untuk melindungi masyarakat dari berbagai resiko yang timbul dari dirinya -baik karena kecelakaan, sakit, atau meninggal dunia- maupun dari lingkungannya. Secara konseptual jaminan sosial terdiri dari bantuan sosial dan asuransi sosial. Bantuan sosial, atau yang kerap disebut juga sebagai bantuan publik, dapat berbentuk tunjangan uang, barang atau pelayanan sosial tanpa memperhatikan 
kontribusi atau premi dari penerima. Sedangkan asuransi sosial adalah jaminan yang hanya diberikan kepada para peserta sesuai dengan kontribusinya, yakni premi atau tabungan yang dibayarkan (Muchtar 2014, Laksono 2016).

Konstitusi memerintahkan negara untuk menjamin kesehatan seluruh warga negara, sejak lahir hingga tutup usia. Jaminan kesehatan merupakan sistem yang telah berdiri sejak lama dan sangat diperlukan oleh masyarakat. Jaminan kesehatan merupakan pendorong pembangunan dan strategi penting dalam penanggulangan kemiskinan. Dalam Peraturan Pemerintah Nomor 76/2015 Tentang Perubahan atas Peraturan Pemerintah Nomor 101/ 2012 tentang Penerima Bantuan Iuran (PBI) Jaminan Kesehatan. menjelaskan bahwa, Jaminan Kesehatan adalah jaminan berupa perlindungan kesehatan agar peserta memperoleh manfaat pemeliharaan kesehatan dan perlindungan dalam pemenuhan kebutuhan dasar kesehatan yang diberikan kepada setiap orang yang telah membayar iuran dan/atau yang iurannya dibayarkan oleh pemerintah.

Meski UU 40/2004 tentang Sistem Jaminan Sosial menyatakan bahwa peserta Jaminan Kesehatan Nasional adalah seluruh warga Indonesia tanpa terkecuali, namun pada faktanya masih banyak warga masyarakat yang belum terjangkau dalam program ini. Pada maret 2018, Badan Penyelenggara Jaminan Sosial Kesehatan (BPJS Kesehatan) mengungkapkan terdapat enam puluh delapan juta masyarakat Indonesia belum terdaftar dalam program Jaminan Kesehatan Nasional-Kartu Indonesia Sehat (JKN-KIS), terlebih jumlah orang miskin yang seharusnya menjadi Penerima Bantuan Iuran (PBI) yang kewajiban iuran bulanannya ditanggung oleh APBN dan APBD Kabupaten/Kota Depok. Data BPJS ini menarik, terutama jika dilihat dalam data mikro, bagaimana jumlah PBI seringkali tidak sinkron dengan jumlah orang miskin, dan bagaimana orang miskin yang seharusnya menjadi PBI justru terlewatkan (lihat Huraerah 2019).

Kota Depok misalnya, pada medio 2019, mencatat 1.456 .175 orang yang terdaftar di JKN-KIS, jumlah tersebut sudah termasuk Penerima Bantuan Iuran (PBI) yang kewajiban iuran bulanannya ditanggung oleh APBN sebesar 280.553 orang dan APBD Kota Depok 174.847 orang. Data ini menarik, sebab BPS Kota Depok hanya mencatat jumlah orang miskin sebesar 2,07 persen dari populasi, atau sekitar 49.394 orang (BPS 2019, Hantoro 2020), sedangkan jumlah PBI mencapai 455.400 orang, atau selisih 406,006 orang. Di sisi lain, Dinas Sosial Kota Depok bahkan melansir data bahwa lebih dari sepuluh ribu orang miskin di Depok belum terdaftar sebagai PBI JKN-KIS, hal ini dapat dilihat dari sedikitnya penerima Program Keluarga Harapan dan Kartu Sembako yang tercatat sebagai PBI JKN KIS. Salah satu sektor yang terlupakan adalah para pemulung, utamanya adalah pemulung perempuan kepala keluarga yang berasal dari rumahtangga miskin (Putri \& Noer 2020).

Data Sekretariat Nasional Perempuan Kepala Keluarga (2014), sebagian kelompok perempuan kepala keluarga yang berada di Indonesia adalah berasal dari kelompok masyarakat termiskin. Kemiskinan yang dialami oleh perempuan akan bertambah buruk jika ia berstatus sebagai kepala keluarga. Pasalnya sebagai orang tua tunggal perempuan menanggung beban lebih berat yaitu satu sisi harus mencukupi kebutuhan hidup keluarga dan disisi yang lain harus berperan sebagai ibu dan ayah bagi anakanaknya (lihat Khairunnisa \& Noer 2020). Kelompok ini umumnya berusia 20-60 tahun, dan sebagian dari mereka buta huruf dan tidak pernah duduk di bangku sekolah dasar, 
bekerja sebagai buruh tani atau pekerja sektor informal dengan pendapatan rata-rata kurang dari sepuluh ribu rupiah per hari, dan menghidupi antara 1-6 orang tanggungan.

Berdasarkan data Tim Nasional Percepatan Penanggulangan Kemiskinan (2015), jumlah rumah tangga dengan Kepala Rumah Tangga Perempuan dengan status kesejahteraan 40\% terendah sejumlah 4.375.957 jiwa. Dari jumlah tersebut, tiga peringkat teratas berada di wilayah Jawa. Peringkat pertama adalah Jawa Timur dengan jumlah 990.903 jiwa, peringkat kedua adalah Jawa Barat dengan jumlah 796.183 jiwa dan peringkat ketiga adalah Jawa Tengah dengan jumlah 780.811 jiwa. Kota Depok yang berada di wilayah Jawa Barat memiiki jumlah rumah tangga dengan Kepala Rumah Tangga Perempuan status kesejahteraan 40\% terendah sejumlah 16.561 jiwa. Menurut data yang tersedia, untuk kategori lapangan pekerjaan kepala rumah tangga di Kota Depok yang paling banyak adalah profesi pemulung dengan jumlah sejumlah 16.178 jiwa (BPS Depok 2019).

Pemulung adalah orang-orang yang mengambil barang-barang bekas atau sampah tertentu untuk proses daur ulang. Pengelolaan sampah di Kota Depok dilakukan oleh masyarakat dari tingkat rumah tangga sampai pengolahan pada Tempat Pemrosesan Akhir (selanjutnya disingkat TPA) di Cipayung, Kota Depok. TPA adalah tempat untuk memproses dan mengembalikan sampah ke media lingkungan secara aman bagi manusia dan lingkungannya. Pekerjaan ini tidak hanya didominasi oleh laki-laki, namun juga perempuan. Pada faktanya profesi sebagai pemulung memang tak mudah. Apalagi bagi perempuan yang juga sebagai kepala keluarga, pekerjaan ini menjadi tantangan tersendiri. Banyaknya kepala rumah tangga yang bekerja menjadi pemulung di Kota Depok merupakan satu hal yang saling berhubungan dengan jumlah produksi sampah yang dihasilkan oleh masyarakatnya. Pada 2018, produksi sampah yang dihasilkan berkisar 750 ton-800 ton per/hari, jumlah ini meningkat hingga 1.300 ton per/hari atau naik 61,53 persen pada 2019 (Badan Pusat Statistik Kota Depok 2019). Peningkatan jumlah sampah tidak dibarengi dengan peningkatan jumlah pemulung. Pada saat ini, pemulung yang berada di TPA Cipayung berjumlah 175 orang, dengan jumlah pemulung perempuan sebanyak 68 orang.

Keberadaan pemulung merupakan satu bagian peran penting dalam pemrosesan akhir sampah. Pemulung merupakan mata rantai pertama dari industri daur ulang. Melalui peran pemulung, sampah yang sampai di TPA dipilah sesuai kategori sampah yang nantinya akan dimanfaatkan kembali dan menjadi sumber penghasilan bagi pemulung. Meski demikian, pada faktanya, sampah adalah sumber penyakit bagi siapapun yang berada disekitarnya. Penyakit-penyakit yang dapat timbul seperti diare, disentri, kolera, tipus, hepatitis dan penyakit lainnya. Timbunan sampah akan menimbulkan pencemaran udara dan bau tidak sedap sehingga akan menganggu pernapasan. Dengan kondisi yang ada, perempuan kepala keluarga yang bekerja sebagai pemulung perlu mendapatkan kemudahan akan akses akan jaminan kesehatan.

Tulisan ini berfokus pada kehidupan pemulung perempuan kepala keluarga dalam memperoleh haknya mendapatkan jaminan dan layanan kesehatan sebagai hak dasar warga negara. Berbeda dengan penelitian tentang kehidupan pemulung yang lebih berfokus pada persoalan ekonomi (Abida, Setiawan, \& Mutiah 2015, Wiyatna, Utama, \& Marhaeni 2015, Maryati, Aryani, \& Atmaja 2018), persoalan sosial (Amirudin 2012, 
Simmau 2013, Yoserizal \& Anggarini 2015, Asliati 2017), strategi adaptif (Kawalo, Ngangi, \& Loho 2016), maupun kesediaan untuk berubah (Kristina, Christiani, Ishak, \& Puspitasari 2017, Sukarniati, Suripto, \& Khoirudin 2017, Panjaitan \& Afrilia 2020), penelitian ini berfokus pada kehidupan pemulung perempuan. di sisi lain, berbeda dengan kajian pemulung perempuan yang berfokus pada ekonomi keluarga (Tatambihe, Kandowangko, \& Kawung 2017, Kauntu \& Suraya 2018), relasi kehidupan kehidupan keluarga (Pangaribuan \& Sidiq 2017), dan persoalan relasi sosial perempuan kepala keluarga (Saputri 2016).

Tulisan ini lebih pada kajian antropologi kebijakan, secara umum bertujuan untuk mendedahkan bagaimana kebijakan kesehatan berjalin-berkelindan dengan persoalan konstruksi gender, pemiskinan, stereotipe dan anggapan tentang orang miskin dalam kehidupan sehari-hari para pemulung perempuan kepala keluarga di TPA Cipayung. Secara spesifik, tulisan ini berfokus pada dua hal: Pertama, bagaimana kehidupan para pemulung perempuan mempertahankan kehidupan sehari-hari mereka. Kedua, bagaimana para pemulung perempuan memperoleh haknya atas jaminan kesehatan. Hal ini penting, sebab perempuan relatif lebih rentan terhadap berbagai resiko terkait dengan siklus kehidupan dan peranannya di keluarga, namun karena perempuan lebih banyak terlibat dalam kegiatan ekonomi informal, perempuan lebih tidak terlindungi oleh skema jaminan sosial (Putri \& Noer 2020). Bagi perempuan, terutama yang berperan ganda sebagai ibu dan ayah dalam rumah tangga, akses pelayanan kesehatan menjadi hal yang amat penting. Keberadaan jaminan kesehatan dan kemudahan dalam meraih pelayanan kesehatan sebagai salah satu faktor pendukung di dalam keberlangsungan hidupnya.

\section{Metode}

Penelitian dilaksanakan di TPA Cipayung Kota Depok. TPA merupakan tempat pemrosesan akhir sampah dimana sebagian besar sampah yang dihasilkan oleh masyarakat Kota Depok ditempatkan disini. Dalam pemrosesan akhir ini, melibatkan banyak pekerja salah satunya yang berperan adalah pemulung. Menggunakan metode etnografi, penelitian dilakukan dengan wawancara mendalam, pengamatan terlibat dan studi dokumentasi. Penelitian ini mengikuti kehidupan lima orang pemulung perempuan kepala keluarga di TPA Cipayung sebagai informan kunci. Selain itu, informan lain yang menjadi sumber informasi dalam penelitian ini adalah pihak pemberi layanan kesehatan yaitu Kepala Tata Usaha Puskesmas Cipayung Kota Depok dan Staff monitoring lapangan TPA Cipayung Kota Depok.

\section{Hasil dan pembahasan}

\section{- Profil Informan}

Sukinah, berusia 54 tahun, sejak bercerai dari sang suami, Jamhari, enam tahun lalu, beliau telah menjadi kepala keluarga. Sukinah merupakan warga asli Cipayung, memiliki 5 orang anak yang semunaya telah menikah, saat ini tinggal bersama satu cucunya. Untuk pendidikan, Sukinah tidak sampai menyelesaikan pendidikan sekolah dasarnya. Sukinah tinggal di rumah warisan orangtuanya, dengan kondisi rumahnya sangat tidak layak untuk ditinggali. Meski rumah tersebut beberapa tahun lalu 
mendapat bantuan untuk renovasi dari pemerintah melalui program Rumah Tinggal Layak Huni (RTLH), namun bantuan tidak pernah sampai. Sukinah telah bekerja sebagai pemulung sejak TPA Cipayung ada. Menurutnya, keberadaan TPA memberikan keuntungan baginya. Dari hasil memulung, ia memperoleh uang sejumlah Rp.150.000200.000 perminggu yang digunakan untuk memenuhi kebutuhannya sehari-sehari.

Aminah berusia 69 tahun, beliau sudah menjadi kepala keluarga kurang lebih selama 20 tahun. Aminah merupakan warga asli Cipayung, memiliki 7 orang anak, yang 6 diantaranya sudah menikah. Aminah tidak pernah bersekolah, buta huruf, dan tinggal bersama satu orang anaknya yang belum menikah. Aminah tinggal di rumah petak warisan ayahnya, rumah yang ditinggalinya saat ini, dulu pernah juga mendapat bantuan renovasi dari pemerintah, namun bantuannya hanya dapat digunakan untuk mengganti atap rumah dengan asbes. Aminah sudah lama sekali menjadi pemulung di TPA, jika dihitung dalam tahunan, beliau tidak dapat mengingatnya. Penghasilan yang dia dapatkan dari hasil memulung kurang lebih sebesar Rp.400.000 pertiga minggu. Menurutnya, penghasilan tersebut tidak dapat mencukupi kebutuhannya sehari-hari.

Zahroh berusia 53 tahun, telah menjadi kepala keluarga sejak diceraikan suaminya enam tahun silam. Zahroh merupakan warga asli Cipayung, memiliki 2 orang anak yang telah menikah, satu diantaranya masih tinggal bersama di rumahnya. Zahroh juga belum pernah mengenyam pendidikan sekolah dasar, meski dapat membaca sedikit. Tempat tinggalnya sangat berdekatan dengan lokasi TPA terutama pada area pengolahan kompos. Rumah yang ada saat ini merupakan bedeng yang berdiri di tanah milik pengairan, ia pernah memperoleh bantuan program Rumah Tinggal Layak Huni sebesar tiga juta rupiah yang habis digunakan untuk membayar seluruh hutang. Zahroh sudah menjadi pemulung sejak selama 22 tahun, sejak anaknya yang kedua masih balita. Keputusan untuk menjadi pemulung dia lakukan karena menurutnya tidak ada pekerjaan lain. Karena di daerah tempat tinggalnya sulit mendapatkan pekerjaan. Penghasilan yang iya dapat dari hasil memulung berkisar Rp.300.000 perbulan atau terkadang dia menjual hasil barang yang dia dapatkan seminggu sekali yaitu berkisar Rp.180.000.

Sailah berusia 50 tahun, telah menjadi kepala keluarga hampir empat belas tahun. Sailah berasal dari Garut, pindah ke Cipayung karena ikut suaminya. Sailah sempat merasakan pendidikan dasar hingga lulus, memiliki 2 orang anak, 1 telah menikah dan tidak tinggal bersamanya. Jadi dalam satu rumah Sailah hanya tinggal bersama satu anak lakilakinya. Saat ini Sailah tinggal di rumahnya kontrakan, beberapa tahun lalu pernah mendapatkan bantuan dari pemerintah untuk renovasi kamar mandi berupa bantuan kloset jongkok, namun akhirnya rumah tersebut ia jual. Pada awalnya, menjadi pemulung merupakan salah satu cara dalam mengurangi beban suaminya. Hasil yang dia dapatkan menjadi tambahan untuk kebutuhan sehari-hari. Penghasilan yang dia dapatkan dalam satu minggu berkisar 500.000. Sejak suaminya meninggal, Sailah menanggung semua kebutuhan rumah tangga.

Jauhara berusia 60 tahun, merupakan warga Bogor, dan sudah menjadi kepala keluarga sudah hampir 25 tahun silam. Jauhara memiliki tiga orang anak, dua telah menikah, dan satu mengalami gangguan kejiwaan dan saat ini dirawat sendiri di rumahnya. Seluruh anaknya masih tinggal di dalam rumahnya saat ini. Sejak kepergian suaminya yaitu 
tepat ketika anak ketiganya kelas $3 \mathrm{SD}$, Jauhara berjuang menghidupi keluarganya. Jauhara sempat merasakan pendidikan dasar sampai kelas 5, dan sudah mencari peruntungan di TPA sudah hampir 17 tahun. Dia mencari barang-barang yang dapat dijual tersebut bersama anaknya yang mengalami keterbelakangan mental. Sebelum menjadi pemulung, beliau sempat bekerja di salah satu konveksi di daerah Cipayung. Namun karena pekerjaan tersebut cukup melelahkan fisik dan matanya, diapun beralih menjadi pemulung. Dari hasil memulung, informan E memperoleh Rp. 500.000 sd Rp. 700.000,- perdua minggu sekali atau bahkan sebulan sekali. Penjualan ini tidak menentu tergantung jumlah barang yang di kumpulkan. Rumah ini juga merupakan salah satu rumah yang mendapatkan bantuan renovasi program Rumah Tinggal Layak Huni, hanya saja uang bantuan yang diperoleh dipergunakan seluruhnya untuk membayar hutang.

\section{- Para pemburu sampah}

Cipayung adalah salah satu kecamatan di Kota Depok, menurut data Tim Nasional Percepatan Penanggulangan Kemiskinan (2019) jumlah rumah tangga dengan Kepala Rumah Tangga Perempuan dengan status kesejahteraan 40\% terendah sejumlah 1.762 jiwa. Dengan spesifikasi berdasarkan usia dibawah 45 tahun yaitu sejumlah 293 jiwa, usia 45-59 tahun sejumlah 787 jiwa, dan usia 60 tahun keatas sejumlah 682 jiwa. Jumlah ini termasuk dalam jumlah pemulung perempuan kepala keluarga yang bekerja di TPA Cipayung. Di dalam TPA Cipayung, dari 175 pemulung yang ada, jumlah pemulung laki-laki lebih banyak dibandingkan dengan jumlah pemulung perempuan. Untuk pemulung laki-laki, berjumlah 135 orang dan pemulung perempuan berjumlah 68 orang, dengan 35 orang diantaranya adalah perempuan kepala keluarga. Rentang usia para pemulung beragam, mulai dari anak-anak yang secara substansial menganggur dipaksa untuk membantu ekonomi rumah tangga hingga usia di atas 60 tahun. Lebih dari separuh pemulung tidak mengecap pendidikan SLTP, mereka memang sempat sekolah namun hanya sekedar dapat baca tulis dan keterampilan berhitung dasar.

Asliyati (2017) menjelaskan, bahwa gambaran tepat tentang pemulung tidak pernah diperoleh secara pasti, karena lemahnyaperhitungan statistik karena para peneliti mengalami kesulitan untuk menghitung mereka.Jumlah pemulung tidak pernah konstan, tetapi mengalami pasang surut. Pekerjaan pemulung jelas tidak mudah, namun tidak memerlukan modal dan ketrampilan tinggi sehingga banyak orang yangterjun menjadi pemulung dalam tempo yang singkat.

Ada cukup banyak alasan menjadi pemulung, namun alasan yang paling banyak dikemukakan adalah profesi ini tidak memerlukan persyaratan tertentu, seperti pendidikan, ketrampilan dan modal, tidak ada alternatif pekerjaan lain, pekerjaan ini mudah dilakukan dan ada relasi yang sudah bekerja lebih dulu di kota. Alasan berikutnya, pekerjaan memulung memiliki resiko rendah karena hanya bermodalkan tenaga, maka pemulung sudah dapat merasakan hasilnya secara langsung sepanjang si pemulung tersebut rajin bekerja (lihat Amirudin 2012, Kawalo, Ngangi, \& Loho 2016, Maryati, Ariyani, \& Atmaja 2018). Dalam konteks para perempuan kepala keluarga, adalah keterputusan dan/atau ketiadaan akses terhadap pendidikan yang mengakibatkan menjadi pemulung adalah pilihan terbaik yang mereka punya, belum lagi karena mereka pada awalnya ikut memulung dengan suami mereka, sebelum pada 
akhirnya ditinggalkan baik cerai maupun meninggal dunia, meninggalkan pemulung sebagai satu-satunya profesi yang mereka ketahui dan lakukan.

Pendapatan sebagai pemulung sangat tergantung dari jumlah sampah yang dapat dikumpulkan. Setiap harinya, rata-rata setiap pemulung dapat mengumpulkan 2-4 karung sampah perhari. Sampah-sampah tersebut umumnya terdiri dari botol plastik, botol beling, kemasan makanan, dan selebihnya terdiri atas sisa-sisa makanan seperti sayur-sayur untuk makanan ternak. Aktivitas bekerja pemulung sangat bergantung pada jam operasional TPA dan kemampuan serta pola bekerjanya dalam mengumpulkan sampah bernilai jual. Pekerjaan sebagai pemulung dipengaruhi oleh faktor kecekatan, keterampilan, dan daya tahan fisik. Keadaan ini yang membuat para pemulung memiliki pola bekerja tertentu dalam mengumpulkan sampah di TPA baik itu dari masa, hari bekerja dan jam bekerja mengumpulkan sampah di TPA, awal pemulung datang mengumpulkan sampah di TPA maupun cara yang digunakan dalam mengumpulkan sampah. Hal ini mengakibatkan perbedaan pola bekerja dari setiap pemulung. Masing-masing individu pemulung telah menciptakan pola bekerjanya sendiri yang terbentuk dari kebiasaan aktivitas bekerja. Pola bekerja yang terbentuk dari kebiasan bekerja pemulung ini sedikit banyak menentukan tingkat pendapatan yang diterima dari penjualan sampah untuk memenuhi segala kebutuhan hidup keluarga.

Dengan produksi sampah hingga 1400 ton perhari, TPA Cipayung menerima sampah mulai jam 11 malam hingga pukul 5 pagi, sedangkan para pemulung baru bisa bekerja mulai jam 7 hingga 5 sore. Berbeda dengan beberapa TPA lain yang membedakan slot bekerja antara pemulung laki-laki dan perempuan (lihat Oni, Subair, \& Nasution 2018), di TPA Cipayung tidak ada perbedaan waktu bekerja, sehingga para pemulung bebas bekerja kapan saja di seluruh kolam penampungan sampah di TPA Cipayung.

Pemulung merupakan ujung tombak bagi para pedagang sampah daur ulang, persoalanya pemulung sangat bergantung pada pengepul untuk menentukan harga. Pengepul dan pabrik yang menentukan harga untuk harga yang dikumpulkan oleh pemulung. Meski hal itu yang mendasari pembatasan aliran pendapatan ke pemulung, namun tidak banyak inisiatif diantara mereka untuk membentuk serikat kerja guna menuntut harga yang lebih tinggi, atau bekerjasama meningkatkan produktivitas. Dalam hal ini, yang dilakukan oleh bukan menambah jam kerja mencari pulungan tetapi lebih ke keterampilan pemulung dalam memilah sampah. Hal ini yang nampaknya muncul dalam komunitas pemulung di TPA Cipayung, bahwa mereka sangat dibatasi pada jam kerja yang disesuaikan dengan jam kerja TPA Cipayung, sehingga mereka berstrategi dalam memilah jenis sampah yang mereka kumpulkan.

Persoalan lain yang juga muncul adalah disparitas harga jual antara pemulung laki-laki dan pemulung perempuan. Pemulung laki-laki, umumnya menerima harga yang lebih tinggi dari pemulung perempuan. Hal ini disebabkan pada kuantitas dan jenis sampah yang dikumpulkan pemulung laki-laki lebih banyak, terutama botol beling dan kardus yang lebih besar dan lebih berat. Sedangkan pemulung perempuan lebih banyak fokus pada sampah plastik kemasan yang lebih ringan dan lebih murah. Di sisi lain, pemanfaatan uang hasil mengumpulkan sampah juga berbeda peruntukkannya, di mana pemulung perempuan lebih banyak menghabiskan uang mereka untuk kebutuhan harian rumahtangga dan jajan anak-anaknya. 


\section{- Negara dan jaminan kesehatan}

Jaminan Kesehatan Nasional-Kartu Indonesia Sehat pada dasarnya menanggung hampir seluruh jenis penyakit. Berikut daftar beberapa penyakit yang ditanggung oleh JKN-KIS: kusta, stroke, kanker, jantung, hipertensi, tumor, kencing manis, malaria, asma, bronkitis, sirosis hepatitis, leukemia, operasi ceasar, persalinan vaginal, gagal ginjal, thalasemia, hemofilia dan masih banyak lainnya. Peserta penerima manfaat Jaminan Kesehatan, dapat memanfaatkan pelayanan kesehatan yang disediakan. Hal ini menyangkup, antara lain: Pelayanan Kesehatan Tingkat Pertama yang meliputi Rawat Jalan Tingkat Pertama (RJTP) dan Rawat Inap Tingkat Pertama (RITP), Pelayanan Kesehatan Rujukan Tingkat Lanjutan yang meliputi Rawat Jalan Tingkat Lanjutan (RJTL) dan Rawat Inap Tingkat Lanjutan (RITL), pelayanan gawat darurat, pelayanan ambulan, dan alat kesehatan.

Dengan menggunakan analisis Aksesibilitas (Suharto 2013, Laksono 2016, Putri \& Noer 2020), dapat dilihat bagaimana akses terhadap jaminan terhadap perempuan pemulung kepala keluarga. Pendekatan ini berfokus pada konsep kesesuaian antara kebutuhan pasien dan kemampuan sistem dalam memenuhi kebutuhan tersebut, antara lain: (1) ketersediaan, jumlah tenaga dokter dan pelayanan kesehatan lainnya, (2) aksesibilitas, kaitan secara geografis antara provider pelayanan dengan masyarakat sebagai pengguna, (3) akomodasi, sistem pelayanan kesehatan yang berkaitan dengan kemudahan pemanfaatan, (4) keterjangkauan, kemampuan finansial masyarakat untuk memanfaatkan pelayanan, dan (5) akseptabilitas, direpresentasikan dengan sikap pengguna terhadap pelayanan, dan sebaliknya.

Dalam dimensi ketersediaan, fokus utamanya pada dua hal: ketersediaan JKN-KIS dan ketersediaan layanan kesehatan. JKN-KIS pada dasarnya memang ditujukan untuk masyarakat dengan kategori prasejahtera. Pemulung perempuan kepala keluarga yang mencari peruntungan di TPA Cipayung adalah termasuk didalamnya. Pemulung perempuan kepala keluarga merupakan penerima manfaat dari JKN-KIS PBI yang iurannya dibayarkan oleh pemerintah.

Persoalannya adalah, model pendataan JKN-KIS yang didasarkan pada pencatatan sipil mempersyaratkan semua penerima JKN-KIS harus memiliki Kartu Tanda Penduduk dan Kartu Keluarga. Bagi para informan, kepemilikan KTP dan KK bukan masalah serius yang harus mereka hadapi. Meski Sukinah dan Zahroh masih mengupayakan untuk menghapus nama suami mereka dari KK, namun hal tersebut tidak berpengaruh pada pendataan nama mereka sebagai pemerima JKN-KIS. Pada awalnya, para pemulung ini tidak masuk ke dalam JKN-KIS. Mereka harus membayar sendiri iuran yang disetorkan melalui TPA Cipayung. Sejak 2014 silam, para pemulung, dimotori oleh Jauhara, meminta kepada TPA Cipayung untuk disediakan layanan kesehatan bagi mereka, terlebih salah satu anak Jauhara yang mengalami gangguan mental tidak dapat diurus kesehatannya.

Hal ini direspon oleh TPA dengan mengikutsertakan pada pemulung ini ke JKN-KIS PBI dan menyediakan fasilitas kesehatan yang dapat diakses oleh para pemulung. Di sekitar TPA tersedia beberapa pelayanan kesehatan yang dapat dikunjungi oleh pemulung, antara lain Puskesmas Cipayung dan klinik yang secara rutin dibuka oleh 
TPA setiap hari Rabu. Beberapa tenaga kesehatan disediakan pada pelayanan kesehatan di TPA maupun Puskesmas Cipayung. Hal ini sebagai bentuk dukungan akan terselenggaranya pelayanan kesehatan bagi pemulung dan masyarakat sekitar Cipayung. Selain itu pula, di sekitar wilayah kelurahan Cipayung, terdapat beberapa klinik bukan milik pemerintah yakni milik swasta yang juga dapat diakses.

Dalam pengamatan, tidak muncul hambatan yang signifikan. Dengan terdaftarnya seluruh pemulung perempuan kepala keluarga menjadi peserta penerima manfaat JKNKIS PBI. Selain ketersediaan JKN-KIS, dukungan yang hadir adalah ketersediaan tempat pelayanan kesehatan. Tempat pelayanan kesehatan sangat dekat dengan lokasi TPA juga tempat tinggal pemulung perempuan kepala keluarga. Salah satu persoalan krusial dalam ketersediaan terbatasnya dokter obgyn tetap yang dapat diakses oleh para perempuan ini. Sebab dokter-dokter yang tersedia di klinik TPA maupun Puskesmas lebih banyak dokter umum. Beberapa poli, seperti poli gigi dan poli kulit hanya buka sekali dalam satu minggu, itupun pada hari dan jam kerja yang menyulitkan perempuan untuk dapat berobat kesana.

Dari sisi aksesibilitas, pekerjaan memulung yang telah dijalankan rupanya tidak banyak memberikan pengaruh yang besar pada aspek kesehatan pemulung perempuan kepala keluarga. Selama bertahun-tahun menjadi seorang pemulung, penyakit yang pernah dialami adalah penyakit yang biasa dialami oleh masyarakat umum. Seperti sakit kepala, pusing, lambung, hipertensi dan sebagainya. Penyakit yang berasal dari lingkungan TPA itu sendiri belum pernah dialami, seperti penyakit kulit dan ISPA. Meskipun demikian, dalam menjalankan pekerjaan tersebut, sesekali diantara pemulung perempuan kepala keluarga pernah mengalami kecelakaan kerja. Hal ini sangatlah wajar melihat kondisi TPA yang dikelilingi oleh alat-alat berat dan gunungan sampah.

Kesehatan pemulung perempuan yang bekerja di TPA pada dasarnya tidak dijaminkan oleh pihak TPA, namun demikian perhatian TPA kepada pemulung perempuan kepala keluarga tetap ada yaitu dengan melibatkan pemulung perempuan kepala keluarga dalam setiap acara bakti sosial terutama yang berkaitan dengan bidang kesehatan. Sebagai fasilitas kesehatan tingkat pertama, puskesmas menyediakan layanan khusus bagi perempuan yang idealnya dapat dimanfaatkan oleh pemulung perempuan yaitu pelayanan skrining kesehatan untuk resiko penyakit kronis seperti kanker serviks (pap smear). Selain itu puskesmas juga menyediakan pelayanan kesehatan ibu dan anak. Pelayanan kesehatan ini berupa pemeriksaan kondisi ibu hamil, membantu persalinan, perawatan pada masa nifas, menyusui, program keluarga berencana, serta imunisasi dasar bagi bayi dan anak.

Hambatan utama adalah kurangnya sosialisasi kepada masyarakat akan pengetahuan JKN-KIS. Meski pendistribusian KIS sudah beberapa tahun lalu, nyatanya masih banyak diantara pemulung perempuan kepala keluarga yang belum paham manfaat kartu tersebut. Hal demikian terjadi karena, pada saat pergantian kartu dari Jamkesmas/Jamkesda ke KIS PBI masyarakat hanya menerima saja melalui rukun tetangga di wilayah tempat tinggalnya masing-masing tanpa penjelasan detail tentang cara penggunaannya. Selain itu juga, fakta dilapangan masih ditemukan KIS yang dipegang bukan oleh pemiliknya, hal ini terjadi karena kurangnya ketelitian pada saat 
pendistribusian kartu. Dengan kurangnya pengetahuan tentang JKN-KIS, beberapa diantara perempuan kepala keluarga sampai saat ini belum pernah memanfaatkan JKNKIS yang ada.

Hambatan lain adalah pada sisi pemanfaatan pelayanan kesehatan yang disediakan oleh TPA maupun Puskesmas Cipayung. Seluruh pemulung perempuan kepala keluarga yang menjadi informan memiliki JKN-KIS PBI, namun sebagian dari pemulung perempuan kepala keluarga enggan untuk menggunakan jaminan tersebut di pelayanan kesehatan yang ada. Pemulung perempuan kepala keluarga lebih memilih untuk berkunjung ke pelayanan kesehatan berbayar yang bahkan berada di luar wilayah tempat tinggalnya. Hal ini terjadi karena pemulung perempuan ini merasa tidak sanggup dengan antrian yang sangat memakan waktu di Puskesmas Cipayung. Sebagai gambaran, dari proses mendaftar hingga tiba ke ruang konsultasi, para pemulung ini bisa menunggu hingga empat jam, sedangkan dari ruang konsultasi hingga penebusan obat bisa menunggu hingga dua jam. Sehingga untuk berobat saja bisa memakan waktu enam jam, yang artinya harus mengorbankan waktu bekerja mereka.

Kehadiran JKN-KIS PBI pada dasarnya bertujuan dimanfaatkan oleh seluruh masyarakat penerimanya. Namun disisi lain, adanya JKN-KIS PBI ini mengubah paradigma sehat masyarakat. Karena merasa memiliki jaminan kesehatan, masyarakat lebih sering datang ke pelayanan kesehatan padahal sakitnya hanya kategori ringan. Misal pegal-pegal, flu atau pusing ringan. Dengan kondisi demikian kuota di pelayanan kesehatan setiap harinya membeludak dan menjadi salah satu kendala pada proses pelayanan itu sendiri.

Di dalam klinik TPA atau Puskesmas, alasan beberapa diantara pemulung perempuan kepala keluarga enggan untuk memanfaatkan fasilitas kesehatan yang disediakan adalah pemulung perempuan ini seringkali dinomorduakan, seringkali pula diminta untuk pulang dulu ke rumah agar bisa mandi baru ke Puskesmas atau klinik, belum lagi sikap masyarakat yang menjauh dan menutup hidung ketika mereka melintas atau duduk menunggu panggilan. Sikap dan respon petugas layanan kesehatan yang demikian mendorong pemulung perempuan ini merasa kehadirannya mengganggu masyarakat yang berobat termasuk diantaranya tenaga kesehatan yang ada. Karena pelayanan kesehatan yang diberikan bersamaan dengan jam kerja pemulung perempuan kepala keluarga, dengan kondisi baju yang kotor menjadi faktor penyebab beberapa diantara pemulung perempuan kepala keluarga enggan berkunjung kesana. Para pemulung ini lebih memilih untuk menyelesaikan bekerja, pulang ke rumah untuk mandi, baru kemudian ke klinik untuk berobat, meski mereka harus membayar penuh untuk obat-obatan tersebut.

Pemulung perempuan kepala keluarga yang setiap harinya berhadapan dengan tumpukan sampah, dikelilingi beberapa alat berat dan berdekatan dengan sumber penyakit memang tidak mendapat jaminan secara khusus dari pihak TPA. Hal ini menjadi salah satu kendala bagi pemulung perempuan di lapangan. Salah satu pemulung perempuan pernah mengalami kecelakaan kerja yaitu tertimbun sampah hingga tidak sadarkan diri dan kejadian ini menjadi tanggung jawabnya pribadi. Dari pengobatan hingga proses pemulihan, dan pihak TPA tidak memberikan bantuan apapun. Beberapa kasus seperti terperosok ke dalam kolam sampah hingga tertimpa 
peralatan adalah kasus-kasus yang acapkali muncul dan membayangi kehidupan para pemulung di TPA.

Pada level makro, kendala yang muncul pada proses pengajuan rekomendasi KIS APBD. Pengajuan KIS APBD direkomendasikan melalui Dinas Sosial Kota Depok. Namun selama berjalannya proses ini, pihak yang merekomendasikan tidak memiliki data jumlah seluruh penerima KIS PBI. Hal ini sangat disayangkan mengingat data merupakan hal yang penting untuk dapat diketahui oleh masyarakat dan dapat menjadi dasar untuk rekomendasi KIS PBI selanjutnya. Dalam konteks JKN-KIS PBI di TPA Cipayung misalnya, ada dua puluh enam orang pemulung, delapan diantaranya perempuan, yang namanya tidak lagi terdaftar sebagai penerima JKN-KIS PBI, konsekuensinya mereka tidak lagi dibiayai oleh APBN/ APBD dalam iuran KIS mereka.

Dimensi akomodasi dalam aksesibilitas jaminan kesehatan bagi pemulung perempuan dapat dilihat dari waktu pelayanan kesehatan itu diberikan. Pada awalnya, Klinik di TPA dibuka pada pukul sepuluh pagi sampai pukul dua belas siang, namun karena banyak permintaan, terutama dari pemulung perempuan yang harus menyelesaikan bekerja dan menyiapkan makan siang, klinik dibuka hingga pukul dua siang. Sejak medio 2019, lagi-lagi atas permintaan, penutupan pelayanan kesehatan di Klinik TPA disesuaikan dengan jumlah pasien yang datang, jika antrian pasien sudah tidak ada, pelayanan kesehatan di TPA ditutup. Persoalannya adalah, pelayanan kesehatan di TPA dilaksanakan hanya satu minggu sekali yaitu pada hari rabu. Pelayanan kesehatan yang waktunya terbatas ini menjadi salah satu hambatan pemulung perempuan, karena sakit yang datang tak mesti tepat di waktu pelayanan kesehatan TPA diselenggarakan.

Fasilitas kesehatan lain adalah Puskesmas Cipayung yang dibuka selama 24 jam, sehingga bisa diakses kapan saja, termasuk dalam kondisi darurat. Di titik ini juga selalu muncul masalah. Pada saat ini pendaftaran di Puskesmas Cipayung dilakukan secara dalam jaringan, baik bagi masyarakat penerima JKN-KIS PBI, BPJS mandiri, maupun pribadi. Namun pada pelaksanaannya, jalur online tidak dapat selalu digunakan karena terdapat kendala pada sistem jaringan yang ada. Akhirnya, alur pendaftaran lebih sering dilakukan secara luar jaringan. Selain itu hambatan lain pada alur pendaftaran adalah berbagai tahapan yang harus dilewati oleh penerima JKN-KIS PBI yang ingin berobat. Pemulung perempuan harus melewati beberapa tahapan pada proses pendaftaran sampai mendapatkan obat. Proses ini terlalu berbelit dan memakan waktu yang sangat panjang penerima manfaat yang pada saat itu dalam kondisi sakit dan sebetulnya memerlukan proses yang cepat. Di sisi lain, alur pendaftaran juga tidak dibedakan baik pengguna KIS maupun bukan pengguna, dan pelayanan kesehatan yang diberikan di TPA tidak memisahkan antara pemulung atau non pemulung, seringkali memicu tindakan diskriminatif antara pemulung dan masyarakat umum.

Pelayanan kesehatan pada TPA menyediakan fasilitas obat, namun memang tidak semua obat tersedia disana. Hal ini menjadi salah satu kendala yang harus dihadapi oleh pemulung perempuan kepala keluarga. Keterbatasan obat menyebabkan pemulung perempuan kepala keluarga harus mencari dan membeli obat yang dibutuhkan di tempat lain seperti toko obat, apotik, atau tempat pelayanan kesehatan lainnya. Selain keterbatasan obat, sistem rujukan seringkali tidak disediakan di puskesmas bagi 
pemulung yang memang memerlukan, sehingga menyulitkan untuk para pemulung ketika ingin memeriksakan di fasilitas kesehatan tingkat lanjut.

Dari sisi keterjangkauan, fasilitas kesehatan yang disediakan untuk pemulung perempuan di Puskesmas Cipayung dan TPA nyatanya memang tidak perlu mengeluarkan biaya sepeserpun. Pelayanan kesehatan yang diberikan sepenuhnya menjadi tanggung jawab penyelenggara jaminan kesehatan karena pemulung perempuan memiliki KIS dan untuk di TPA menjadi tanggung jawab TPA itu sendiri. Dengan pelayanan kesehatan yang gratis, pemulung perempuan dapat dengan mudah menjangkaunya, namun beberapa diantara pemulung perempuan kepala keluarga yang memang tidak pernah menggunakan layanan kesehatan tersebut tetap rela mengeluarkan biaya untuk kesehatannya.

Dimensi akseptabilitas pada konteks pelayanan kesehatan untuk pemulung perempuan dapat dilihat dari seluruh pelayanan kesehatan yang diberikan atas pertimbangan kebutuhan pemulung perempuan. Beberapa kebutuhan masyarakat diidentifikasi berdasarkan hasil survei-survei sebelumnya. Pelayanan kesehatan yang disedikan oleh TPA pada dasarnya sebagai bentuk tanggung jawab TPA kepada masyarakat sekitar. Pelayanan kesehatan yang diberikan memberikan manfaat dan kesan positif terhadap pemulung perempuan selaku penerima manfaat JKN-KIS. Mulai dari yang berkaitan dengan pulihnya penyakit yang dialami sampai pada kemudahan karena akses yang lebih dekat dengan lokasi tempat tinggal pemulung perempuan kepala keluarga.

Pelayanan kesehatan yang diberikan pemberi layanan kesehatan sejatinya ingin dilakukan secara maksimal. Beberapa proses dilakukan untuk menjaga hal-hal yang dapat saja terjadi seperti human error pada saat memberikan pelayanan kepada masyarakat, namun proses tersebut belum dapat dipahami secara utuh oleh masyarakat. Pelayanan kesehatan diselenggarakan baik bagi pemulung perempuan kepala keluarga maupun masyarakat sekitar TPA. Hal ini merupakan salah satu cara untuk menjaga hubungan yang baik antar lingkungan sekitarnya, dan untuk terus meningkatkan pelayanan yang ada, pihak TPA maupun Puskesmas Cipayung memberikan sarana untuk mengungkapkan masukan dan saran akan pelayanan kesehatan yang diberikan.

Pada sisi pemulung perempuan, pelayanan kesehatan yang selama ini didapatkan cukup baik namun beberapa diantara mereka merasa kurang dimanusiakan oleh beberapa pemberi layanan kesehatan. Karena menggunakan JKN-KIS PBI, pemulung perempuan kepala keluarga merasa kurang dipedulikan dan kurang dilayani dengan cepat. Seringkali alur pendaftaran dan pelayanan dipersulit, bahkan seringkali disampaikan bahwa obat yang sebetulnya ada namun disampaikan kosong, sehingga mereka harus mencari obat-obatan tersebut di luar. Hal ini menjadi salah satu hambatan yang dirasakan oleh pemulung perempuan.

\section{- Perempuan dan pemiskinan}

Narasi perempuan pemulung sesungguhnya menceritakan narasi yang seturut sama: bahwa pemiskinan adalah bagian dari realitas hidup perempuan. dalam konteks TPA Cipayung, kehidupan para pemulung perempuan menggambarkan kompleksitas kehidupan perempuan yang, bahkan secara konseptual dan legal, tidak diakui sebagai kepala keluarga (Mien 2005, Sekretariat Nasional Perempuan Kepala Keluarga 2014). 
Secara umum para pemulung perempuan ini berbagi karakteristik yang sama: tingkat pendidikan rendah sehingga tidak mempunyai keterampilan apapun, hidup di permukiman yang kumuh, tidak memiliki jaminan pekerjaan sebab kapanpun mereka bisa saja terusir dari TPA, dan meski memiliki jaminan sosial namun tidak selalu dapat digunakan tanpa diskriminasi dan peliyanan baik dari penyedia layanan kesehatan hingga masyarakat sekitar yang menggunakan layanan kesehatan yang sama.

Di sisi lain, kondisi mereka bukanlah kemiskinan, melainkan pemiskinan, sebuah kondisi struktural yang membuat anggota atau kelompok masyarakat untuk selalu dalam posisi miskin dan bergantung. Hal ini terjadi karena struktur sosial yang ada membuat anggota atau kelompok masyarakat tidak menguasai sarana ekonomi dan fasilitas penjunjang secara merata. Dengan demikian sebagian anggota masyarakat tetap miskin, dan meski jumlah total produksi yang dihasilkan oleh masyarakat jika akumulasi bisa terlihat besar, namun untuk mencapai hal tersebut adalah sebuah ketidakmungkinan karena ketidakberdayaan mereka dalam tawar menawar sosial. Dalam penjualan barang hasil memulung misalnya, mereka sama sekali tidak berdaya menghadapi para pengepul maupun pabrik yang dapat mengatur harga. Bahkan di antara sesame pemulung sendiri, posisi perempuan pemulung paling rentan karena keterbatasan fisik dan waktu, menyebabkan mereka sangat sulit bersaing.

Para perempuan pemulung ini adalah gambaran vulgar tentang pemiskinan, bagimana mereka umumnya tidak banyak berdaya, ruang geraknya serba terbatas, dan cenderung kesulitan untuk terserap dalam sektor-sektor yang memungkinkan mereka dapat mengembangkan usahanya (lihat Noer 2018, Khairunnisa \& Noer 2020, Putri \& Noer 2020). Para perempuan ini tidak memiliki keterampilan apapun selain memilah sampah, bahkan tidak memiliki pengetahuan, dan dalam dejarat tertentu, keengganan untuk mengubah sampah menjadi barang yang punya nilai ekonomis. Sehingga, jangankan untuk mengembangkan diri menuju ke taraf sejahtera, sedangkan untuk bertahan menegakkan hidup fisik pada taraf yang subsistem bagi mereka hampir merupakan hal yang mustahil, bila tidak ditopang oleh jaringan dan pranata sosial di lingkungan sekitarnya. Para pemulung ini mengembangkan sistem pranata untuk saling membantu di antara sesame mereka, baik melalui mekanisme arisan maupun saling pinjam. Terlebih mereka harus pula mengurus anak dan cucu yang tinggal dalam rumah yang sama dengan mereka.

Sebagai kepala keluarga, yang secara konsep hukum diperuntukkan bagi laki-laki, para perempuan ini mendapat hambatan paling besar dalam sektor permodalan. Dalam hal ini, modal produktif berupa asset tanah atau rumah misalnya, hingga saat ini masih menggunakan nama ayah atau bekas suami. Kepemilikan asset berupa peralatan untuk memulung juga peninggalan dari suami atau orangtua mereka yang sudah sangat lapuk dan sederhana, yang menyebabkan mereka kalah bersaing dengan pemulung laki-laki yang punya peralatan lebih kuat.

Di sisi lain, para pemulung perempuan juga sangat rentan dalam sumber-sumber keuangan. Ada cukup banyak cerita bagaimana pemulung perempuan kepala keluarga yang mencoba meminjam ke bank, namun kendala utamanya adalah bank hanya menerima suami sebagai penandatangan kontrak, sedangkan mereka bercerai yang hingga saat ini tidak bisa diurus karena persoalan birokrasi di kelurahan yang sangat 
berbelit-belit. Kerentanan ekonomi, dengan hanya pendapatan sekitar 300ribu perbulan, padahal mereka harus menghidupi anak dan cucu, menyebabkan para pemulung perempuan ini harus berpikir keras dalam mengatur ekonomi rumahtangga. Sesungguhnya JKN-KIS yang mereka miliki dapat membantu secara signifikan, sebab mereka tidak perlu mengeluarkan sepeserpun biaya untuk berobat, namun karena pelayanan yang seringkali mendiskriminasi, pada akhirnya pos untuk kesehatan tetap harus diambil dari pos keuangan rumahtangga. Hal ini menjadi persoalan serius, sebab dalam kebijakan layanan kesehatan, segala bentuk tindakan diskriminatif adalah terlarang, namun kenyataan lapangan bicara hal yang berbeda.

\section{Kesimpulan}

Pertama, kehidupan pemulung perempuan sesungguhnya sangat berisiko untuk perempuan, terlebih dengan posisi mereka sebagai kepala keluarga. Dengan pendapatan yang sangat minim, mereka harus tinggal di rumah yang bahkan tidak layak huni, meski dikatakan bahwa mereka memperoleh bantuan renovasi bangunan, namun jumlah yang diterima sangat minim dan justru digunakan untuk hal lain. Kehidupan para pemulung ini menggambarkan betapa kondisi yang mereka hadapi mendorong mereka untuk tetap miskin, dan karenanya pemiskinan adalah realitas kehidupan sehari-hari. Dalam konteks inilah sesungguhnya negara berperan, jika negara tidak bisa menjamin kehidupan sosial ekonomi, setidaknya negara bisa menjamin akses terhadap kesehatan.

Kedua, meski negara secara nyata telah memberikan jaminan kesehatan bagi semua warganya, namun jaminan tidak serta merta langsung hadir dan dapat dinikmati oleh semua orang. Seluruh informan memperoleh jaminan kesehatan melaui JKN-KIS, dan karena mereka berstatus PBI, maka seluruh iuran kepesertaan diambil dari APBN/APBD. Meski demikian, tidak berarti bahwa kehidupan mereka menjadi lebih nyaman, sebab tidak jaminan bahwa nama mereka dapat saja hilang dari data penerima JKN-KIS PBI. Hal ini muncul dalam beberapa kasus, di mana ada beberapa orang pemulung yang namanya hilang, yang mengakibatkan mereka kehilangan haknya untuk memperoleh layanan kesehatan secara cuma-cuma.

Ketiga, dari sisi pelayanan kesehatan, para pemulung perempuan ini dapat mengakses seluruh layanan kesehatan, seperti deteksi kanker serviks, pemeriksaan ibu hamil, persalinan, perawatan nifas dan program keluarga berencana. Dari pelayanan kesehatan yang disediakan, pemulung perempuan kepala keluarga mendapatkan fasilitas seperti pemeriksaan umum, obat-obatan dan pelayanan rujukan. Meski tidak ada pembedaan antara pemulung dan non pemulung di tempat pelayanan kesehatan, namun, para pemulung ini masih merasakan diskriminasi dalam pelayanan kesehatan, yang mengakibatkan penggunaannya belum dimanfaatkan secara maksimal. Pada umumnya, karena persoalan waktu dan tindakan diskriminasi yang seringkali mereka terima, mendorong sebagian dari mereka lebih memilih berkunjung ke tempat pelayanan kesehatan milik swasta yang harus membayar. Negara bisa menjamin akses, namun gagal memastikan akses tersebut terbuka dan dapat dipergunakan oleh mereka yang memang membutuhkan. 


\section{Referensi}

Abida, DHN., Setiawan, PH., \& Mutiah, N. (2015). Pendekatan Keruangandalam Mengurai Struktur Sosial Ekonomi Pemulung di Tempat Pembuangan Sampah Terpadu Piyungan Bantul." Pelita, 10(1), 42-54

Amirudin, L. (2012). Lingkar Kuasa Kehidupan Komunitas Pemulung Pandesari Kota Malang. Kawistara, 2(2), 105-224

Asliati. (2017). Kondisi Sosial Ekonomi Komunitas Pemulung di Tempat Pembuangan Akhir (TPA) Muara Fajar Rumbai Pekanbaru: Fenomena dan Solusi. Sosial Budaya, 14(2), 150-164

Badan Penyelenggara Jaminan Sosial Kesehatan. (2017). Panduan Praktis Sistem Rujukan Berjenjang. Penerbit Badan Penyelenggara Jaminan Sosial Kesehatan (2018). Panduan Layanan Bagi Peserta Jaminan Kesehatan Nasional Kartu Indonesia Sehat (JKN-KIS). Penerbit Badan Penyelenggara Jaminan Sosial Kesehatan

Badan Pusat Statistik Kota Depok. (2019). Kota Depok Dalam Angka 2019. Penerbit Badan Pusat Statistik Kota Depok

Hantoro, J. 2020. BPS: Banyak Orang Kaya di Depok, tapi Tak Ada Budaya Filantropi. Tempo. metro.tempo.co/read/1299265/bps-banyak-orang-kaya-di-depok-tapitak-ada-budaya-filantropi

Huraerah, A. (2019). Kebijakan Perlindungan Sosial: Teori dan Aplikasi Dynamic Governance. Nuansa Cendikia

Kauntu, RR., \& Suraya, RS. (2018). Perempuan Pemulung Dalam Mendukung Ekonomi Keluarga di Pesisir Teluk Kendari. Etnoreflika, 7(3), 212-221

Kawalo, AYK., Ngangi, CR., \& Loho, AE. (2016). Kajian Bertahan Hidup Pemulung di Tempat Pembuangan Akhir Sampah Kelurahan Sumompo Kecamatan Tuminting Manado. ASE, 12(1), 47-54

Khairunnisa, DA., \& Noer, KU. (2020). Strategy for Empowering Poor Families through an Integrated Program to Increase the Role of Women towards Prosperous Healthy Families in Depok, West Java. Proceeding of International Conference on Social Sciences, Universitas Muhammadiyah Jakarta, 1(1)

Kristina, HJ., Christiani, A., Ishak, \& Puspitasari, M. (2017). Ergonomi Partisipasi Dalam Memprediksi Tingkat Kesediaan Untuk Perubahan Kualitas Hidup Keluarga Tukang Sampah/Pemulung. Jurnal Teknik Industri, 12(3), 171-180

Laksono, Agung, dkk. (2016). Aksesibilitas Pelayanan Kesehatan di Indonesia. Yogyakarta: PT Kanisius

Maryati, T., Ariyani, LP. \& Atmaja, BN. (2018). Mengolah Sampah menjadi Rupiah: Latar Belakang Sosial dan Perubahan Citra Pemulung di TPA Desa Bengkala, Buleleng, Bali. Jurnal Kajian Bali, 8(2), 197-214

Menteri Sosial Republik Indonesia. (2013). Keputusan Menteri Sosial Republik Indonesia Nomor 147/HUK/2013 Tentang Penetapan Penerima Bantuan Iuran Jaminan Kesehatan

Mien, R. (2005). Fenomena Sosial Kehidupan Perempuan Kepala Keluarga Miskin (Studi Kasus di Kecamatan Pacet-Kabupaten Cianjur Jawa Barat). Tesis. Universitas Indonesia

Muchtar. (2014). Implementasi Kebijakan Perlindungan Sosial Bagi Penerima Bantuan Iuran Jaminan Kesehatan-Indonesia Sehat (Studi Kasus di Jawa Barat dan Jambi). Resume Quick Research, 1(1), 16-24

Noer, KU. (2018). Mereka yang Keluar dari Rumahnya: Pengalaman Perempuan Madura di Bekasi. Jurnal Inada: Kajian Perempuan Indonesia di Daerah Tertinggal, Terdepan, dan Terluar, 1(1), 55-74 
Oni, A., Subair, \& Nasution, E. (2018). Strategi Nafkah Pemulung di Tempat Pembuangan Sampah Akhir Taosapu, Ambon. Jurnal Fakultas Ushuluddin dan Dakwah IAIN Ambon, 2(1), 16-27

Pangaribuan, S., \& Sidiq, SS. (2017). Intensitas Ibu Rumah Tangga Pemulung dalam Mewujudkan Kehidupan Keluarga di Kelurahan Sail Kecamatan Tenayan Raya. Jurnal Online Mahasiswa Fakultas Ilmu Sosial dan Ilmu Politik Universitas Riau, 4(1), $1-15$.

Panjaitan, UD., \& Afrila, D. (2020). Pengaruh Sosial Ekonomi Orangtua Terhadap Tingkat Pendidikan Anak Pemulung di Tempat Pembuangan Akhir Sampah Talang Gulo Kota Jambi. Scientific Journal of Economic Education, 4(1), 71-78

Pemerintah Kota Depok. (2014). Peraturan Daerah Kota Depok Nomor 5 Tahun 2014 Tentang Pengelolaan Sampah

. (2018). Profil Kesehatan Kota Depok Tahun 2017. Penerbit Dinas Kesehatan Kota Depok. Depok

Presiden Republik Indonesia. (2013). Peraturan Presiden RI No. 12 Tahun 2013 Tentang Jaminan Kesehatan

. (2015). Peraturan Pemerintah Republik Indonesia No. 76 Tahun 2015 Tentang Perubahan Atas Peraturan Pemerintah RI No. 101 Tahun 2012 Tentang Penerima Bantuan Iuran Jaminan Kesehatan Kesehatan (2018). Peraturan Presiden RI No. 82 Tahun 2018 Tentang Jaminan (2019). Peraturan Presiden RI Nomor 75 Tahun 2019 Tentang Perubahan Atas Peraturan Presiden No. 82 Tahun 2018 Tentang Jaminan Kesehatan

Putri, FD., \& Noer, KU. (2020). There's no room for poor people: some notes on the accessibility of National Health Guarantee for women scavenger in Depok, West Java. Proceeding of International Conference on Social Sciences, Universitas Muhammadiyah Jakarta, 1(1)

Saputri, EY. (2016). Peran Wanita Sebagai Kepala Keluarga Dalam Melaksanakan Fungsi Keluarga Di Kelurahan Sungai Merdeka Kecamatan Samboja. eJournal SosiatriSosiologi, 4(2), 212-226

Sekretariat Nasional Perempuan Kepala Keluarga. (2014). Menguak Keberadaan Dan Kehidupan Perempuan Kepala Keluarga: Laporan Hasil Sistem Pemantauan Kesejahteraan Berbasis Komunitas. Lembaga Penelitian SMERU

Simmau, S. (2013). Perubahan Sosial pada Komunitas Pemulung di TPAS Antang Matangapa Kota Makassar. Socius, 14(3), 64-70

Suharto, E. (2013). Kemiskinan dan Perlindungan Sosial di Indonesia: Menggagas Model Jaminan Sosial Universal Bidang Kesehatan. Alfabeta

Sukarniati, L., Suripto, \& Khoirudin, R. (2017). Determinan Kebahagiaan Pemulung (Studi Kasus di Tempat Pembuangan Sampah Terpadu Piyungan). I-Economic, 3(1), 38-50

Tatambihe, L., Kandowangko, N., \& Kawung, E.J.R. (2017). Kontribusi Ibu Rumahtangga Sebagai Pemulung Sampah Dalam Meningkatkan Ekonomi Keluarga. E-Journal Acta Diurna, 6(2), 1-16

Tim Nasional Percepatan Penanggulangan Kemiskinan. (2015). Perjalanan Menuju Jaminan Kesehatan (JKN). Penerbit Tim Nasional Percepatan Penanggulangan Kemiskinan

Undang-Undang Republik Indonesia. (1974). Undang-Undang Republik Indonesia Nomor 1 Tahun 1974 tentang Perkawinan

Sosial . (2004). Undang-Undang Nomor 40 Tahun 2004 Tentang Sistem Jaminan . (2011). Undang-Undang Nomor 24 Tahun 2011 Tentang Badan Penyelenggara Jaminan Sosial 
Wiyatna, MYP., Utama, MS., \& Marhaeni, AAIN. (2015). Analisis Pengaruh Faktor Sosial Demografi dan Aktivitas Ekonomi Terhadap Kesejahteraan Keluarga Pemulung di Kota Denpasar. E-Jurnal Ekonomi dan Bisnis Universitas Udayana, 4(4), 282-295

Yoserizal \& Angraini, M. (2015). Hubungan Patron-klien antara Pengepul dengan Pemulung di Kota Pekanbaru." Jurnal Online Mahasiswa Fakultas Ilmu Sosial dan Ilmu Politik Universitas Riau, 2(2), 15-24 